\title{
Speedy Justice and Timeless Delays: The Validity of Open-Ended "Ends-of-Justice" Continuances Under the Speedy Trial Act
}

\author{
Greg Ostfeld $\uparrow$
}

The federal district courts of the United States face a peculiar time crunch each time they confront a new criminal prosecution. Every year, federal judges must cope with tens of thousands of criminal cases which have become increasingly complex and time-consuming. ${ }^{1}$ At the same time, the courts are procedurally constrained in terms of the amount of time they are permitted to devote to each new case. The Speedy Trial Act ${ }^{2}$ ("STA") mandates dismissal of any federal criminal case in which an indictment is not issued within thirty days of arrest or in which a trial does not begin within seventy days of indictment or arraignment. Designed by Congress to reduce recidivism and increase deterrence through the efficient administration of justice, the STA paradoxically threatens to thwart its own objectives whenever a complex and time-consuming prosecution comes before the courts.

The drafters of the STA were cognizant of this danger and constructed the statute to accommodate it. Recognizing the practical need to reconcile the STA with the many unavoidable delays intrinsic to the criminal process, the drafters enumerated nine specific exclusions that toll the STA's time limits. ${ }^{3}$ Eight of the exclusions are specifically targeted to common sources of delay such as pretrial motions and joining of new codefendants. The ninth confers discretion upon judges to grant a continuance when necessary to serve the "ends of justice." These exclusions, espe-

† B.A. 1995, George Washington University; J.D. Candidate 1998, The University of Chicago.

1 See Committee on Long Range Planning of the Judicial Conference of the U.S., Proposed Long Range Plan for the Federal Courts 10 (1995) (observing that "the average [federal criminal] case has increased in complexity"); Rory K. Little, Myths and Principles of Federalization, 46 Hastings L J 1029, 1043 (1995) (recognizing that although the number of federal criminal cases has remained relatively stable from year to year, the character of those cases has "shifted dramatically towards larger numbers of narcotics and weapons offenses").

2 Pub L No 93-619, 88 Stat 2076 (1975), codified at 18 USC $\S \S 3131-74$ (1994).

318 USC $\$ 3161(\mathrm{~h})$.

418 USC $\$ 3161(\mathrm{~h})(8)$. 
cially the ends-of-justice exclusion, have become indispensable to the practical judicial administration of complex federal cases. ${ }^{5}$

Unfortunately, the STA conspicuously fails to specify whether there is a time limit requirement for ends-of-justice continuances. It fails to address whether judges may issue openended continuances in cases where the trial judge is unable to determine precisely how long the ends-of-justice exclusion should last. The text of the statute does not speak directly to the issue of open-ended continuances. The legislative history, which offers contradictory policy statements and countervailing judicial interests, only offers limited guidance. As a matter of policy, the STA contains a competing set of goals; while strict time limits deter crime and reduce recidivism, ends-of-justice continuances provide courts with needed flexibility when delaying a trial is in the public interest.

The STA's ambiguity on this important issue has created substantial confusion among the federal courts of appeals. Despite the relative frequency with which complex cases arise, courts have yet to resolve whether the STA permits an ends-ofjustice continuance to be open-ended in such cases. To date, seven circuits have staked out positions on the issue. This Comment divides those positions into three categories: the "definite duration" approach prohibits open-ended ends-of-justice continuances, stating that every continuance must be specifically limited in duration and justified on the record; the "reasonable duration" approach permits open-ended ends-of-justice continuances so long as they are reasonable in length; and the "reasonable relation" approach permits open-ended ends-of-justice continuances only so long as they can continue to be justified by reference to their original rationales.

This Comment argues that the "reasonable relation" approach provides the best balance between the STA's goal of judicial efficiency and the practical flexibility embodied in the endsof-justice exclusion. Under the "reasonable relation" approach, a court should tie the duration of the continuance to its rationale; it should grant an open-ended continuance only when it is impossible to determine an end date and the rationale for the continuance supports the open-ended duration. Part I summarizes the

- Federal trials rarely begin within the STA's seventy-day time limit. In fact, "the average time for disposition of federal criminal cases is more than five months." Little, 46 Hastings L J at 1051 (cited in note 1), citing Michael V. Bork, Federal Judicial Caseload: A Five-Year Review, 1989-1993 7 (1994). Trial courts rely on the STA's exclusions to prevent dismissal of these cases. The ends-of-justice exclusion in particular is "frequently invoked." Id. 
structure and content of the STA, with particular emphasis on the ends-of-justice exclusion and how it operates. Part II then describes the three different approaches and examines their relative popularity among the appellate courts. Finally, Part III evaluates each approach and argues that the "reasonable relation" approach accords best with the text, legislative history, and district court plans implementing the STA.

\section{THE SPEEDY TRIAL ACT AND THE ENDS-OF-JUSTICE EXCLUSION}

The STA provides that in every federal criminal action an indictment must be filed within thirty days of arrest, ${ }^{6}$ and a trial must begin within seventy days of indictment or arraignment. ${ }^{7}$ Failure to abide by these time limits results in dismissal of the case, either with or without prejudice depending on such factors as the seriousness of the alleged offense and the facts and circumstances surrounding the delay. ${ }^{8}$

To mitigate this rather harsh remedy, several provisions of the STA provide the trial court with the flexibility to accommodate delays that are beyond the court's control. The STA recognizes an extensive list of exclusions that exempt specific types of delay from the statute's time limit computations. ${ }^{9}$ These exclusions accommodate the various non-administrative delays that inevitably arise in the criminal justice context. They provide

- 18 USC $\$ 3161(\mathrm{~b})$ (“Any information or indictment charging an individual with the commission of an offense shall be filed within thirty days from the date on which such individual was arrested or served with a summons in connection with such charges.").

718 USC $\$ 3161(c)(1)$ ("In any case in which a plea of not guilty is entered, the trial of a defendant ... shall commence within seventy days from the filing date (and making public) of the information or indictment, or from the date the defendant has appeared before a judicial officer of the court in which such charge is pending, whichever date last occurs.").

* 18 USC $\$ 3162(a)(1)$ provides:

If, in the case of any individual against whom a complaint is filed ... no indictment or information is filed within the time limit required by section 3161(b) as extended by section $3161(\mathrm{~h})$ of this chapter, such charge against that individual ... shall be dismissed or otherwise dropped. In determining whether to dismiss the case with or without prejudice, the court shall consider, among others, each of the following factors: the seriousness of the offense; the facts and circumstances of the case which led to the dismissal; and the impact of a reprosecution on the administration of this chapter and on the administration of justice.

9 The exclusions are listed in 18 USC $\$ 3161(\mathrm{~h})$. Representative examples include any delay resulting from proceedings or examinations to determine the mental competency or physical capacity of the defendant; trial on other charges; interlocutory appeal; pretrial motions; transportation of defendant from another district or to and from places of examination or hospitalization; consideration of proposed plea agreements; and unavailability of an essential witness. 
courts with the flexibility to address postponements resulting from circumstances such as disposition of pretrial motions, ${ }^{10}$ addition of new codefendants, ${ }^{11}$ and resolution of interlocutory appeals. ${ }^{12}$

Despite the flexibility conferred by these exclusions, only one provides judges with any substantial degree of discretion as to both its applicability and its length. Section 3161(h)(8) permits a court to grant a continuance, on its own motion or at the request of either party, when the court finds that the ends of justice to be served by such a continuance outweigh the best interests of both the public and the defendant in a speedy trial. ${ }^{13}$ In considering whether such a delay serves the ends of justice, judges are directed to consider such factors as the complexity of the case, the availability of counsel, and whether failure to grant a continuance would likely result in a miscarriage of justice. ${ }^{14}$

Notwithstanding the presence of these criteria, substantial uncertainty remains as to when an ends-of-justice continuance is appropriate and what procedures must be followed in granting such a continuance. Indeed, the ends-of-justice continuance provision of the STA has become the subject of intense judicial scrutiny and debate. Cases abound addressing such questions as the circumstances under which ends-of-justice continuances are permissible, ${ }^{15}$ whether the rationale for such continuances must

${ }^{10} 18$ USC $\$ 3161(\mathrm{~h})(1)(\mathrm{F})$.

11 USC $\$ 3161(\mathrm{~h})(7)$.

1218 USC $\S 3161(\mathrm{~h})(1)(\mathrm{E})$.

${ }^{13} 18$ USC § 3161(h)(8) allows exclusion of "[a]ny period of delay from a continuance granted by any judge ... on the basis of his findings that the ends of justice served by taking such action outweigh the best interest of the public and the defendant in a speedy trial."

${ }^{14} 18$ USC \$ 3161(h)(8)(B).

${ }^{15}$ See, for example, United States $v$ Ruth, 65 F3d 599, 606 (7th Cir 1995), cert denied, $116 \mathrm{~S} \mathrm{Ct} 1548$ (1996) (finding an ends-of-justice continuance to be appropriate in response to a defendant's refusal on two occasions to provide handwriting samples); United States $v$ Reavis, 48 F3d 763, 770-71 (4th Cir), cert denied, 115 S Ct 2597 (1995) (finding an endsof-justice continuance appropriate on complexity grounds in a case involving eight attorneys, six defendants, a thirty-three count indictment, and the possibility of a federal death penalty prosecution); United States $v$ Fields, 39 F3d 439, 442-46 (3d Cir 1994) (authorizing an ends-of-justice continuance to prepare pretrial motions and permit plea negotiations to continue); United States $v$ Carroll, 26 F3d 1380, 1390 (6th Cir 1994) (finding an ends-of-justice continuance to be appropriate where a key witness was unable to testify for medical reasons); United States $v$ Smith, 24 F3d 1230, 1234-35 (10th Cir), cert denied, 115 S Ct 270 (1994) (allowing an ends-of-justice continuance where otherwise the defendant would have had only five days to prepare a defense to a new indictment containing eight additional counts); United States v Jones, 23 F3d 1307, 1310-11 (8th Cir 1994) (permitting an ends-of-justice continuance to stand where the defendant's attorney moved to withdraw as counsel after being threatened by the defendant); United States $v$ Occhipinti, 998 F2d 791, 797-98 (10th Cir 1993) (upholding a government request for an ends-of-justice continuance for additional preparation time where the request was not 
be stated in the record, ${ }^{16}$ and whether this statement may be entered into the record retroactively. ${ }^{17}$

The most intractable question surrounding the ends-ofjustice continuance, however, is whether such a continuance may be open-ended in duration. Because neither the text nor the legislative history of the statute explicitly addresses the issue, it has proven to be a particularly difficult problem for courts to resolve. The next Section explores the different judicial solutions offered in response to this statutory silence.

motivated by lack of due diligence); United States v Paschall, 988 F2d 972, 975 (9th Cir), cert denied, 510 US 925 (1993) (approving an ends-of-justice continuance granted when grand jury proceedings were delayed by bad weather); United States $v$ Ortega-Mena, 949 F2d 156, 159-60 (5th Cir 1991) (rejecting continuances granted to prevent conflict with other proceedings on the court's calendar); United States $v$ Gates, 935 F2d 187, 188 (11th Cir 1991) (allowing an ends-of-justice continuance where the defendant's attorney suffered serious physical injury prior to trial); United States $v$ Vega, 860 F2d 779, 786-87 (7th Cir 1988) (reemphasizing that ends-of-justice continuances cannot be granted in response to court congestion, but affirming a continuance based on complexity); United States $v$ Monroe, 833 F2d 95, 98-99 (6th Cir 1987) (allowing exclusion of time expended in preparing pretrial motions under an ends-of-justice continuance when the circumstances support such a continuance); United States $v$ Andrews, 790 F2d 803, 807-08 (10th Cir 1986) (rejecting an ends-of-justice exclusion for delay resulting from a congested court calendar and a judge's other business); United States $v$ Theron, 782 F2d 1510, 1512-14 (10th Cir 1986) (rejecting an ends-of-justice continuance based on complexity, the codefendant's need for preparation time, and the desirability of trying all defendants at once where the defendant had moved for severance from codefendants and was not out on bail); United States v Crane, 776 F2d 600, 602-05 (6th Cir 1985) (holding an ends-ofjustice continuance due to court congestion to be inappropriate); United States $v$ Gallardo, 773 F2d 1496, 1505-06 (9th Cir 1985) (reaffirming that ends-of-justice continuances cannot be premised on court congestion, but holding that a continuance granted in response to a stipulation by both parties that they needed additional time to prepare for trial as a result of delayed rulings on pretrial motions was legitimate).

${ }^{10}$ See, for example, United States v Pasquale, 25 F3d 948, 951-52 (10th Cir 1994) (rejecting time excluded under an ends-of-justice continuance that was not justified contemporaneously on the record); United States $v$ Williams, 12 F3d 452, 460 (5th Cir 1994) (holding that statement of an explicit rationale on the record is not required where the reasons for an ends-of-justice continuance are obvious); United States v Blackwell, 12 F3d 44, 46-47 (5th $\mathrm{Cir}$ 1994) (declaring that failure to set forth a contemporaneous rationale on the record renders an ends-of-justice continuance invalid); United States $v$ Newman, 6 F3d 623, 627 (9th $\mathrm{Cir}$ 1993) (finding dismissal required when the district court failed to state its rationale for granting an ends-of-justice continuance); United States $v$ Crawford, 982 F2d 199, 204-05 (6th $\mathrm{Cir} 1993$ ) (rejecting an ends-of-justice continuance where the district court failed to set forth its findings in favor of the continuance).

${ }^{17}$ See, for example, United States v Spring, 80 F3d 1450, 1456 (10th Cir), cert denied, $117 \mathrm{~S} \mathrm{Ct} 385$ (1996) (distinguishing between entering findings in support of a preexisting ends-of-justice continuance on the record retroactively, which is valid, and granting a new ends-of-justice continuance retroactively, which is invalid); United States $v$ Kelly, 45 F3d 45, 47 (2d Cir 1995) (holding a retroactive ends-of-justice finding to be illegitimate); United States $v$ Fields, 39 F3d 439, 443 (3d Cir 1994) (stating that the district court's rationale for granting an ends-of-justice continuance need not be placed on the record at the time the continuance is granted); United States v Lattany, 982 F2d 866, 879-80 (3d Cir 1992) (noting that a district court cannot retroactively justify unauthorized delays by granting an ends-of-justice continuance). 
II. THE OPEN-ENDED CONTINUANCES CONTROVERSY: THREE CONFLICTING SOLUTIONS

A number of federal courts of appeals have disagreed about whether the STA permits open-ended ends-of-justice continuances. Given the ambiguity of the text and the absence of any significant discussion of the problem in the STA's legislative history, this disagreement is not particularly surprising. Such disagreement is problematic, however, considering the sheer number of complex criminal cases likely to confront the federal courts in any given year.

The courts take one of three approaches: the "definite duration" approach, the "reasonable duration" approach, or the "reasonable relation" approach.

\section{A. The "Definite Duration" Approach}

This approach requires that every ends-of-justice continuance be specifically limited in duration and justified on the record with reference to the criteria set forth in the STA. The Ninth Circuit, the only circuit to apply the "definite duration" test, adopted it in United States $v$ Pollock. ${ }^{18}$ It is the most restrictive solution to the question of open-ended continuances.

In Pollock, the defendant was indicted by a grand jury for federal drug charges on June 19, 1982, 119 days after his arrest. ${ }^{19}$ Two overlapping orders granting ends-of-justice continuances were issued over the course of the pre-indictment delay. The first continuance, granted by a magistrate, excluded the time between March 22 and May 21. The second, granted on separate grounds by the district court judge, excluded the time between April 21 and May $24 .{ }^{20}$ Measured in terms of their specific dates, the two continuances failed to exclude a total of 55 days between arrest and indictment, which ordinarily would constitute a violation of Section 3161(b) of the STA.

The government nevertheless asserted that the delay did not violate the STA's 30-day time limit for indictment. ${ }^{21}$ Because the continuances were granted on separate grounds, the government argued that the time excluded by the second continuance was intended to extend rather than overlap with the time excluded by the first continuance. The government contended, in other words, that each continuance should be treated as an exclusion for a

\footnotetext{
${ }^{18} 726$ F2d 1456 (9th Cir 1984).

${ }^{19}$ Id at 1460 .

${ }^{\infty}$ Id at 1461.

${ }^{21} 18$ USC § 3161(b).
} 
specific number of days rather than an exclusion for a designated period of time: the 61 days excluded by the first continuance should be added to the 34 days excluded by the second continuance, without adjusting the total to account for the 31 overlapping days. ${ }^{22}$ Under that equation, 95 of the 119 days should have been excluded, bringing the delay within the permissible scope of the Act.

The Ninth Circuit rejected the government's proposed formula, observing that, under the "plain meaning" of the two orders, the ends-of-justice continuances excluded "periods of time from particular date to particular date, not for a set number of days at some indefinite time."23 The court then proceeded to outline the "definite duration" approach, holding that "an "ends of justice' extension under Section 3161(b) is proper only if ordered for a specific period of time and justified on the record with reference to the factors enumerated in Section 3161(h)(8)(B)." ${ }^{24}$ The court reasoned that this approach was most consistent with the ends-of-justice provision's purpose:

Congress included the "ends of justice" exclusion of time in recognition that courts need some discretion to deal with otherwise unavoidable delays in the indictment and trial process. The "ends of justice" exclusion was not, however, meant to be a general exclusion for every delay no matter what its source, but was to be based on specific underlying factual circumstances. ${ }^{25}$

Because the continuances in Pollock were not open-ended, the court did not expressly address their legitimacy. The court's analysis of the ends-of-justice exclusion did, however, lay the groundwork for the same court's rejection of open-ended continuances six years later in United States $v$ Jordan. ${ }^{26}$

In Jordan, the defendants were indicted on June 12, 1986, for numerous federal narcotics offenses. The indictment involved a complex narcotics conspiracy and included additional charges against thirty-one codefendants. On July 14, the district court entered an order granting an indefinite ends-of-justice continuance based on the complexity of the case. The trial eventually commenced on November 12, 1987, seventeen months after the initial indictment. The delay was justified solely on the basis of

\footnotetext{
${ }^{22}$ Pollock, 726 F2d at 1461.

${ }^{23}$ Id.

${ }^{2}$ Id (emphasis added).

${ }^{25} \mathrm{Id}$.

915 F2d 563 (9th Cir 1990).
} 
the open-ended ends-of-justice exclusion. ${ }^{27}$

The Jordan court reiterated Pollock's holding that every ends-of-justice continuance must be specifically limited in duration and justified on the record. Jordan thus expressly extended Pollock to prohibit open-ended continuances. ${ }^{28}$ If a more lenient rule were adopted, the court reasoned, "one early 'ends of justice' continuance could exempt the entire case from the requirements of the Speedy Trial Act altogether, and open the door for wholly unnecessary delays in contravention of the Act's purpose."29 Jordan thus makes it clear that the "definite duration" approach is intended to apply broadly to all ends-of-justice continuances. ${ }^{30}$ Since its decision in Jordan, the Ninth Circuit has reaffirmed its belief that the "definite duration" approach adequately vindicates the demands of justice while protecting the STA from the threat of judicial circumvention. ${ }^{31}$

\section{B. The "Reasonable Duration" Approach}

Other circuits have been reluctant to prohibit open-ended continuances outright. Indeed, a majority of appellate courts examining the issue have chosen instead to adopt a "reasonable duration" approach that permits open-ended continuances so long as they are reasonable in length.

The evolution of this approach began with the First Circuit. In United States $v$ Rush, ${ }^{32}$ the defendants were indicted for narcotics offenses in October of 1980 . They were not tried until more than two years later, in December of $1982 .^{33}$ Much of this delay was attributable to valid exclusions for pretrial motions under Section 3161(h)(1)(F). ${ }^{34}$ An ends-of-justice continuance granted on June 4, 1981, accounted for the remainder of the delay. Because ten of the fifteen codefendants were being tried on similar

${ }^{n}$ Id at 565.

${ }^{23}$ Id.

$\approx$ Id at 565-66.

${ }^{\infty}$ See also Walter $v$ United States, 969 F2d 814, 818 (9th Cir 1992) ("Pollock created a simple rule for application to a wide spectrum of 'ends of justice' exclusion cases; to be valid the exclusion must be for a specific period of time and be accompanied by a valid set of reasons based on the statutory factors.").

${ }^{31}$ See United States $v$ Clymer, 25 F3d 824, 829 (9th Cir 1994), quoting Jordan, 915 F2d at 565-66 ("The Speedy Trial Act and its amendments are the product of a series of delicate legislative compromises. .. This delicate balance could be seriously distorted if a district court were able to make a single, open-ended 'ends of justice' determination early in a case, which would 'exempt the entire case from the requirements of the Speedy Trial Act altogether." $)$.

32738 F2d 497 (1st Cir 1984).

3 Id at 501.

34 See id at 502-06. 
charges in another district, disrupting the district court's trial schedule, the district court ordered an ends-of-justice continuance extending from May 18, 1981, "until the time of the commencement of this trial. ${ }^{335}$ The court did not set a specific trial date in the order.

The First Circuit upheld the validity of the open-ended continuance, declaring:

Doubtless it is generally preferable to limit a continuance to a definite period for the sake of clarity and certainty; but at the same time it is inevitable that in some cases, like the present one, a court is forced to order an $(\mathrm{h})(8)$ continuance without knowing exactly how long the reasons supporting the continuance will remain valid. ${ }^{36}$

Like the Ninth Circuit, the First Circuit grounded its decision in the purpose of the ends-of-justice exclusion. The First Circuit, however, interpreted an (h)(8) continuance to have a different purpose: "to make the Speedy Trial Act 'flexible enough to accommodate the practicalities of our adversary system." 37 The court did not think "a rule barring open-ended continuances altogether serves this purpose." ${ }^{\text {s8 }}$

Hence, while the Ninth Circuit sees the ends-of-justice exclusion solely as a provision designed to deal with "otherwise unavoidable delays," the First Circuit interprets it as a broader tool of practicality. Though not enamored of open-ended continuances, the First Circuit accepts them as valid in circumstances where the conditions justifying the continuance are sufficiently indeterminate in duration that the court cannot reasonably be expected to set a specific end date.

One might be tempted to reconcile Rush and Jordan on the basis of their factual differences. After all, Rush involved a situation of truly unavoidable delay, given that the defendant was tied up in another trial, whereas Jordan merely involved complex issues. Clearly, the court's ability to identify a specific end date for the ends-of-justice continuance was far greater in Jordan than in Rush. Given this significant distinction between the cases, one might argue that the Ninth Circuit would reach the same result as the First Circuit were it confronted with a Rush-type scenario.

Such an argument, however, ignores the very strong declarations by the Ninth Circuit that the "definite duration" require-

\footnotetext{
$\because$ Id at 506.

${ }^{35}$ Id at 508.

${ }^{37}$ Id, quoting United States $v$ Mitchell, 723 F2d 1040, 1044 (1st Cir 1983).

${ }^{\approx}$ Rush, 738 F2d at 508.
} 
ment applies in all cases involving ends-of-justice continuances. While it is possible that the Ninth Circuit would have adopted a different rule at the outset had it been confronted with a Rushtype situation, it is quite clear at this point that the court is unwilling to backtrack to accommodate individual cases. Indeed, the Ninth Circuit has indicated in no uncertain terms that it is unwilling even to consider the factual circumstances of individual open-ended continuances anymore. ${ }^{39}$ As such, it is clear that the Rush court's approach constitutes a major departure from the Ninth Circuit's reasoning in Jordan.

The First Circuit further defended this approach on the basis of the speedy trial plan ${ }^{40}$ adopted by the District of Maine, which provides that "[t]he court may grant a continuance under 18 U.S.C. $\$ 3161(\mathrm{~h})(8)$ for either a specific period of time or a period to be determined by reference to an event (such as recovery from illness) not within the control of the government . . .."41 Though not legally bound by the terms of the district court plan, the First Circuit found this plan to address an important concern: the necessity for granting open-ended ends-of-justice continuances in cases requiring particular flexibility.

The Rush court fell short of articulating a full "reasonable duration" standard, but it did hint in dicta that the length of open-ended ends-of-justice continuances might be limited by a reasonableness requirement: "It may well be that some sort of reasonableness limitation is appropriate to prevent continuances from delaying trials unfairly and circumventing the dismissal sanctions in the Speedy Trial Act; but we need not decide at what point, if any, such a limitation might have been exceeded in this case....."42

The first full articulation of the "reasonable duration" standard came from the Third Circuit. In United States $v$ Lattany, ${ }^{43}$ the defendant was indicted for attempted bank robbery on July 27, 1989. The trial began 551 days later, on January 29, 1991.44 As in Rush, the government defended this delay on the basis of a

\footnotetext{
${ }^{3}$ See notes 29-31 and accompanying text.

${ }^{40}$ Section 3165(a) of the STA directs each district court to conduct "a continuing study of the administration of criminal justice in the district court and before United States magistrates of the district," and to "prepare plans for the disposition of criminal cases in accordance with this chapter." 18 USC § 3165(a).

${ }^{42}$ Rush, 738 F2d at 508 n 23 (emphasis added).

${ }^{42}$ Id at 508. See also United States v Pringle, 751 F2d 419, 433 (1st Cir 1984) (suggesting again that open-ended continuances might be limited by a reasonableness requirement, but declining to decide the issue).

4982 F2d 866 (3d Cir 1992).

"Id at 869.
} 
number of STA exclusions. Ultimately, however, the permissibility of the delay depended on the legitimacy of an open-ended ends-of-justice continuance granted on November 30, 1989, in response to a motion by the defendant following numerous changes of counsel. ${ }^{45}$

The Third Circuit held that "open-ended continuances to serve the ends of justice are not prohibited if they are reasonable in length. ${ }^{246}$ In so holding, the court expressed its basic agreement with the Rush court's observation that a rule barring openended continuances threatened to prevent the STA from accommodating the practicalities of the adversarial system. ${ }^{47}$ The Lattany court went beyond the Rush court, however, by explicitly declaring that open-ended ends-of-justice continuances must be reasonable in length.

Like the Rush court, the Lattany court found that the pertinent district speedy trial plan provided strong support for permitting an open-ended ends-of-justice continuance in this case. The speedy trial plan adopted by the Eastern District of Pennsylvania is virtually identical to that of the District of Maine with respect to ends-of-justice continuances. The plan provides that the duration of such continuances may be "determined by reference to an event (such as recovery from illness) not within the control of the government" and that in such instances "the court shall require one or both parties to inform the court promptly when and if the circumstances that justify the continuance no longer exist." 48

Although the court found open-ended continuances permissible, it cautioned trial courts not to let the parties have free reign. It "strongly urge[d]" district courts "not to wait and rely on counsel to inform them when defendants are ready to go to trial, but instead to set deadlines."49 Such an approach, suggested the court, would "avoid the kind of problems presented by this case, not only under the Act but also under defendant's Sixth Amendment right to a speedy trial."

In short, like the Rush court, the Lattany court disfavored open-ended continuances. Though refusing to prohibit them, the court urged that they be used only in extreme cases. The reasonableness requirement might thus be seen as yet another disin-

\footnotetext{
See id at 874.

${ }^{46}$ Id at 868 .

47 Id at 881, citing Rush, 738 F2d at 508.

4 Lattany, 982 F2d at 881.

${ }^{49}$ Id at 883.

"Id.
} 
centive to the use of open-ended continuances and as a tool to prevent their abuse.

Several other circuits examining the question of open-ended continuances under the STA have followed Rush and Lattany. In the time since Lattany was decided, the Fifth ${ }^{51}$ and Tenth ${ }^{52}$ Circuits have entirely endorsed its reasoning. Similarly, the district court for the Northern District of Georgia adopted almost word for word the Rush court's holding with respect to open-ended continuances, and the Eleventh Circuit affirmed both the judgment and the reasoning of the district court without additional comment. $^{53}$

Generally, then, the prevalent approach is to permit openended ends-of-justice continuances so long as they are reasonable in length. Of the seven circuits that have examined the issue, five have adopted some variation of this "reasonable duration" approach. For these courts, permitting a carefully limited category of open-ended continuances achieves the best balance between Congress's desire for efficiency and the practical need for judicial flexibility.

\section{The "Reasonable Relation" Approach}

The third approach to the question of open-ended ends-ofjustice continuances states that such continuances are permissible only so long as their open-ended nature remains reasonably related to the ends of justice. The Second Circuit introduced the "reasonable relation" approach in United States $v$ LoFranco. ${ }^{54}$ In that case, the trial judge issued an order granting an ends-ofjustice continuance that excluded from STA calculations all time from the date of the order until the beginning of trial. ${ }^{55}$ The order

${ }^{51}$ United States $v$ Jones, 56 F3d 581, 586 (5th Cir 1995) (holding that a district court may grant an open-ended continuance in situations where "it is impossible, or at least quite difficult for the parties or the court to gauge the necessary length of an otherwise justified continuance").

${ }^{52}$ United States v Spring, 80 F3d 1450, 1458 (10th Cir), cert denied, 117 S Ct 385 (1996) ("We agree with the First, Third, and Fifth Circuits that, while it is preferable to set a specific ending date for a continuance, there will be rare cases where that is not possible, and an open-ended continuance for a reasonable time period is permissible.").

United States v Burke, 673 F Supp 1574, 1578 (N D Ga 1986) ("This court agrees with the reasoning of the First Circuit in United States $v$. Rush, '[d]oubtless it is generally preferable to limit a continuance to a definite period for the sake of clarity and certainty; but at the same time it is inevitable that in some cases, like the present one, a court is forced to order an $(\mathrm{h})(8)$ continuance without knowing exactly how long the reasons supporting the continuance will remain valid."), affd, 856 F2d 1492, 1494 (11th Cir 1988).

${ }^{54} 818$ F2d 276 (2d Cir 1987).

s Id at 277. 
failed to specify a particular date on which the trial was to commence and therefore was effectively an open-ended ends-ofjustice continuance.

The Second Circuit decided the case without specifically resolving the question of open-ended continuances, concluding instead that the defendant had waived all speedy trial claims by pleading guilty. ${ }^{56}$ Nonetheless, the court discussed the openended continuance in dicta, observing that the ends-of-justice provision "could be interpreted as allowing virtually unlimited delays. ${ }^{157}$ Expressing concerns similar to those articulated by the Ninth Circuit, the court made it clear that such a result would be unacceptable:

We assume that this order was made in anticipation of a particular trial date, thus limiting what might otherwise be a boundless exclusion of time that could undermine the purposes of the Speedy Trial Act. We remind district judges that the length of an exclusion under $\$ 3161(h)(8)$ for a "complex" case, 18 U.S.C. $\$ 3161(h)(8)(B)(i i)$, should reasonably be related to the actual needs of the case, and should not be used either as a calendar control device or as a means of circumventing the requirements of the Speedy Trial Act. ${ }^{58}$

This statement might be read as just another way of applying the Ninth Circuit's "definite duration" approach, in that it appears to require the trial court to set a specific trial date and provide a reasonable justification for the continuance. However, subsequent Second Circuit caselaw indicates that the two approaches are indeed distinct. In United States $v$ Beech-Nut Nutrition Corp, the Second Circuit interpreted LoFranco to endorse open-ended continuances so long as their open-ended nature is reasonably related to the actual needs of the case. ${ }^{59}$

In Beech-Nut, eight defendants were indicted on 470 counts of various corporate crimes on November 5, 1986. On November 14,1986 , the district court found the case to be complex within the meaning of the STA, and granted an ends-of-justice continuance. With regard to when trial would commence, the trial judge said, "I will suspend all other provisions of the Act until we are well down the road in the pretrial proceedings and at that point we will discuss the appropriate date for trial." ${ }^{360}$ The trial did not

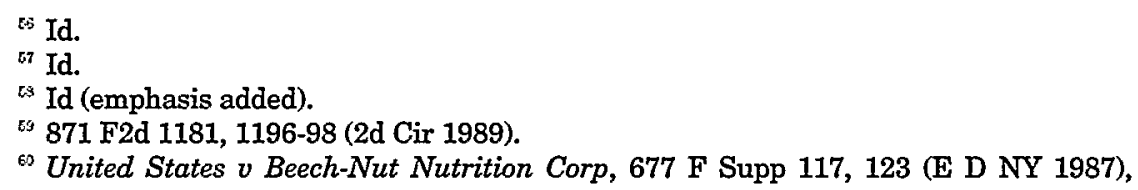


actually commence until November 1987, a full year after indictment.

In assessing the validity of this continuance, the Second Circuit reemphasized that the STA does not permit unlimited delays. Moreover, the court declared that the trial court has an obligation to ensure that the length of a continuance is reasonably related to the needs of the case. ${ }^{61}$ The court went on to explain that these limitations did not necessarily prohibit open-ended continuances:

Though it would perhaps generally be preferable for the court initially to set a tentative trial date, it is not an abuse of discretion in a case such as this to postpone the setting of a date until the extent of the needed pretrial proceedings becomes clearer, so long as there is no intent or appearance that unlimited or undue delay will be permitted. ${ }^{62}$

This statement distinguishes the "reasonable relation" approach from the "definite duration" approach. The Ninth Circuit's "definite duration" approach requires that all ends-of-justice continuances be specifically limited in duration at the time of issuance. In contrast, the Second Circuit's "reasonable relation" approach permits ends-of-justice continuances of uncertain length so long as they are not intended to permit unlimited delay and so long as the ultimate length of the continuance is reasonably related to the needs of the particular case. In this way, the "reasonable relation" approach is clearly more flexible than the. "definite duration" approach.

The distinction between the "reasonable relation" approach and the "reasonable duration" approach is more subtle. The "reasonable duration" approach permits an ends-of-justice continuance to be of any reasonable length once the court has found that a definite end date is not ascertainable at the time it issues the continuance. In contrast, the "reasonable relation" approach demands that the duration of the continuance be directly tied to its rationale. Thus, under the "reasonable relation" approach, an open-ended ends-of-justice continuance is valid only for as long as the circumstances that justified its issuance remain in effect. For example, a ninety-day continuance might be valid under the "reasonable duration" approach if the court felt that ninety days was a reasonable length of time but invalid under the "reasonable relation" approach if the rationale behind the con-

affd, 871 F2d 1181 (2d Cir 1989).

${ }^{61}$ Beech-Nut, 871 F2d at 1196-97.

${ }^{62}$ Id at 1198. 
tinuance did not justify the full ninety days. In this way, the "reasonable relation" approach might invalidate a continuance that the "reasonable duration" approach would find permissible.

Conversely, the "reasonable relation" approach might permit some open-ended ends-of-justice continuances that the "reasonable duration" approach would invalidate. For example, a two-year continuance might be valid under the "reasonable relation" approach if the circumstances behind the condition justified it, while it would be invalid under the "reasonable duration" approach if the court felt that two years was an unreasonable length of time, regardless of the rationale. Because the validity of an open-ended ends-of-justice continuance under the "reasonable relation" approach rests on the continued existence of the circumstances justifying its issuance, such a continuance might remain valid indefinitely - as long as those circumstances continue to exist. Although such a result is to some extent foreclosed by Beech-Nut's requirement that the continuance not have the intent or appearance of permitting unlimited or undue delay, it is nonetheless possible that the "reasonable relation" approach might permit some delays that the "reasonable duration" approach could not countenance. ${ }^{63}$

Perhaps in response to this risk of effectively unlimited delays under Beech-Nut, the Second Circuit has subsequently modified its holding in Beech-Nut by recognizing an independent time limitation requirement on ends-of-justice continuances. This in effect moves the court closer to the Ninth Circuit's "definite duration" approach. In United States $v$ Gambino ${ }^{64}$ the Second Circuit held that:

The length of an exclusion for complexity must be not only limited in time, but also reasonably related to the actual needs of the case. Generally a trial court should set at least a tentative trial date in granting a complex case exclusion. In not doing so, it risks having the exclusion "used either as a calendar control device or as a means of circumventing the requirements of the Speedy Trial Act." ${ }^{35}$

${ }^{\infty}$ Other courts have been reluctant to endorse the Beech-Nut interpretation of LoFranco. In United States $v$ Boyd, for example, the court noted, "LoFranco's dicta is no stronger than a reminder to district court judges that the complex case exclusion should not be used 'either as a calendar control device or as a means of circumventing the requirements of the Speedy Trial Act." 792 F Supp 1083, 1093 (N D Il 1992) (citations omitted).

4 59 F3d 353 (2d Cir 1995), cert denied, 116 S Ct 1671 (1996).

${ }^{65}$ Id at 358 (citations omitted) (emphasis added). 
While not prohibiting open-ended continuances, the Gambino holding does sever the duration requirement of an ends-ofjustice continuance from its rationale requirement. The Gambino holding therefore might appear to prohibit open-ended continuances de facto by requiring that all ends-of-justice exclusions be limited in time, in addition to being reasonably related to the needs of the case. Such a holding would be a substantial retreat from Beech-Nut, which construed the duration of an ends-ofjustice continuance strictly as a function of its rationale. The limitations on an ends-of-justice continuance under Beech-Nut were entirely rationale dependent. No independent time limitations existed. Separating the length of the continuance from its rationale, as Gambino does, thus might be seen to make an openended ends-of-justice continuance virtually impossible by obliging the trial judge to set some time limit regardless of the circumstances justifying the continuance. ${ }^{66}$

Such a conclusion would, however, read too much into the Gambino court's ruling. The fact that Gambino requires only a tentative trial date strongly suggests that its holding still falls short of a full "definite duration" requirement. It is noteworthy that even Beech-Nut disallowed open-ended continuances having the intent or appearance of unlimited or undue delay. Thus, even before Gambino the Second Circuit maintained some limitations on the duration of open-ended ends-of-justice continuances. Gambino simply expanded these limitations into an independent time limitation requirement. In light of that fact, Gambino ought to be read as nothing more than a clarification of the "reasonable relation" approach. The "reasonable relation" approach permits open-ended continuances so long as they remain reasonably related to their rationales, but pursuant to Gambino it does not allow them to continue indefinitely.

\section{PRESERVING THE ENDS OF JUSTICE: FINDING THE RIGHT APPROACH TO OPEN-ENDED CONTINUANCES}

Ultimately, resolving the question of whether the STA permits open-ended ends-of-justice continuances requires reconciling the appellate courts' disparate views of the STA's function within

\footnotetext{
${ }^{65}$ See, for example, United States $v$ Upton, 921 F Supp 100, 102 (E D NY 1995), affd, 78 F3d 65 (2d Cir 1996) (reversing a prior decision upholding the validity of open-ended continuances and holding that, in light of Gambino, "[t]his court is obliged to obey the law as it is pronounced by the Court of Appeals for this circuit and in this regard, the prior determination sanctioning an open-ended excludable delay for complexity was erroneous").
} 
the federal criminal system. As the preceding Part demonstrates, the differences between the three approaches are the result of differing judicial interpretations of the goals of the STA and the ends-of-justice exclusion. Because direct textual and historical evidence addressing the issue of open-ended ends-of-justice continuances is helpful but inconclusive, evaluating the merits of the three approaches is difficult. Given the absence of any express declaration of intent with respect to the issue, the problem of open-ended ends-of-justice continuances must be resolved against the larger backdrop of the STA's text, legislative history, and subsequent implementation in the form of district speedy trial plans. This Part examines Supreme Court interpretations of the STA's text, legislative statements regarding the purpose of both the STA and the ends-of-justice exclusion, and district court implementation of the STA through speedy trial plans. The conclusion, in light of this evidence, is that the "reasonable relation" test best achieves the intent of Congress with respect to both the STA as a whole and the specific ends-of-justice exclusion.

\section{A. Henderson $v$ United States ${ }^{67}$ and the Text of the Speedy Trial} Act

In construing legislation, the court's task "is to give effect to the will of Congress, and where its will has been expressed in reasonably plain terms, that language must ordinarily be regarded as conclusive." ${ }^{\text {"68 }}$ Unfortunately, in addressing the issue of open-ended continuances under the STA, the federal courts of appeals have largely abandoned any expectation of obtaining guidance from the language of the STA. Because the STA is silent with respect to the length of open-ended ends-of-justice continuances, the federal courts of appeals have largely overlooked the text of the statute and instead have relied on whatever reasonable interpretations can be derived from the STA's legislative history.

The text of the statute does not, however, support every interpretation that reasonably follows from the legislative history. Indeed, the plain language of the STA has serious implications for the "reasonable duration" approach. As this Part demonstrates, a careful reading of the STA eliminates the "reasonable duration" approach from the list of plausible judicial solutions. This is because, although the STA does not explicitly address the

\footnotetext{
476 US 321 (1986).

${ }^{63}$ Negonsott v Samuels, 507 US 99, 104 (1993), quoting Griffin v Oceanic Contractors, Inc, 458 US 564, 570 (1982) (internal citations omitted).
} 
duration of ends-of-justice continuances, the structure and language of the statute indicate that a "reasonableness" limitation on such continuances is not a viable interpretation.

The Supreme Court has discussed the notion of reasonableness as it relates to other exclusions under the STA and, in so doing, has provided significant insight into the plain meaning of the STA. In Henderson $v$ United States, the Supreme Court examined the question of whether $\S 3161(h)(1)(F)$, which excludes from speedy trial calculations any period of delay caused by a pretrial motion, is limited in duration solely to reasonable delays. The Court concluded that $\S 3161(\mathrm{~h})(1)(\mathrm{F})$ is not so limited. ${ }^{69}$ In arriving at this decision, the Court contrasted the text of $\S 3161(\mathrm{~h})(1)(\mathrm{F})$ with the text of $\S 3161(\mathrm{~h})(7)$. First, the Court observed that the "plain terms of [\$3161(h)(1)(F)] appear to exclude all time between the filing of and the hearing on a motion whether that hearing was prompt or not."70 Then, the Court noted that if Congress had intended to limit the subsection with a reasonableness requirement, it "clearly knew how" to do it:

in $\S 3161(\mathrm{~h})(7)$, Congress provided for exclusion of a "reasonable period of delay when the defendant is joined for trial with a codefendant as to whom the time for trial has not run and no motion for severance has been granted." Apart from this single instance, every other provision in $\S 3161(\mathrm{~h})$ provides for exclusion of "any period of delay." ""1

One could respond that Henderson's reasoning is inapplicable to the issue of open-ended ends-of-justice continuances because Henderson dealt only with delays from pretrial motions, which are necessarily limited in duration. Given the fundamental differences between open-ended and finite continuances, one might argue that open-ended continuances remain subject to a reasonableness limitation regardless of how one treats closedended continuances under the STA. However, as the Court made clear, its reasoning is applicable to every provision of Section $3161(\mathrm{~h})$. Section $3161(\mathrm{~h})(7)$ is the one and only provision of Section 3161(h) subject to a reasonableness limitation. All other provisions, including Section 3161(h)(8) (the ends-of-justice exclusion), may legitimately encompass any period of delay that falls within their terms. Congress could have attached a specific reasonableness limitation to Section 3161(h)(8) just as easily as it did to Section 3161(h)(7). The fact that it chose not to do so sug-

${ }^{69}$ Henderson, 476 US at 330.

${ }^{70}$ Id at 326.

${ }^{71}$ Id at 326-27. 
gests, under the Henderson Court's reasoning, that no such limitation exists on the ends-of-justice exclusion.

This analysis leads to the conclusion that the "reasonable duration" approach to open-ended continuances is not a viable interpretation of the STA. Most courts currently using the "reasonable duration" approach require that the continuances be reasonable in length. ${ }^{72}$ In light of Henderson's conclusion that only Section $3161(h)(7)$ is subject to a reasonableness limitation, there is reason to doubt that limitation is a viable interpretation of the ends-of-justice exclusion. Indeed, on its face, the text of Section 3161(h)(8) extends to "[a]ny period of delay" to which the ends-of-justice provision otherwise applies. ${ }^{73}$ To burden this provision with a general reasonableness limitation is to impose upon it a meaning contrary to the statute's plain language as interpreted by the Supreme Court in Henderson. ${ }^{74}$ Thus, even though Henderson does not specifically address the question of openended ends-of-justice continuances, the Court's interpretation of the STA throws into question the "reasonable duration" approach.

Henderson does not close off several alternative interpretations of the ends-of-justice exclusion. First, a court might revert to the Rush formulation of the "reasonable duration" approach. ${ }^{75}$ Recall that Rush recognized the validity of open-ended continuances where circumstances so require, but acknowledged only the possibility of a reasonableness limitation. Given that such a limitation is contrary to the text of the STA as interpreted by Henderson, what remains of Rush may be a simple endorsement of open-ended continuances whenever it is impossible for the judge to set an end date at the time the continuance is granted. Under the Rush approach, then, any time a court is forced to order an ends-of-justice continuance without knowing exactly how long the continuance should remain in effect, that court may order an open-ended continuance unhindered by any general time limitations.

${ }^{72}$ See text accompanying notes 44-53.

${ }^{73} 18$ USC $\$ 3161(\mathrm{~h})(8)(\mathrm{A})$.

${ }^{36}$ The Henderson Court did acknowledge that such a limitation, though unsupported by the text of the STA, might nonetheless be imposed by district courts through their speedy trial plans. Henderson, 476 US at 328 ("Congress clearly envisioned that any limitations should be imposed by circuit or district court rules rather than by the statute itself. Such rules, developed pursuant to $\S 3166(f)$, should provide the assurance of a speedy disposition of pretrial motions."). However, it appears from the Model Statement of Time Limits and Procedures and various cases that few if any courts have imposed any such formal time limitations under their speedy trial plans. See notes 101-03 and accompanying text.

${ }^{75}$ See text accompanying notes $32-42$. 
Although this alternative approach is more consistent with the text of the STA as interpreted in Henderson, it is vulnerable to the criticism of the Second and Ninth Circuits that the exception could consume the rule. ${ }^{76}$ Once the conditions are met for a single open-ended continuance, absent some form of time limitation, that continuance could be used to delay trial indefinitely.

Second, a court still could, consistent with Henderson, adopt the "reasonable relation" approach. This approach permits courts to continue to grant open-ended continuances in circumstances of unavoidable indeterminacy, but still limits the duration of such continuances by tying length to rationale. In contrast to the Rush approach, under which meeting the critical threshold for openended continuances would be sufficient to justify any subsequent delay, the "reasonable relation" approach requires that an openended continuance be justified in an ongoing manner. That is, the open-ended continuance remains valid only so long as keeping the continuance open-ended is reasonably related to the ends of justice. When the court can plausibly assign a specific end date to the continuance, the ends of justice would no longer be served by keeping the continuance open-ended. Just as a delay for a pretrial motion remains valid only as long as the motion remains unresolved, so too under the "reasonable relation" approach an open-ended continuance remains valid only as long as a specific end date cannot be assigned.

This approach might present administrative difficulties for a court attempting to determine that the circumstances justifying an open-ended continuance no longer exist. But these difficulties are not insurmountable. The court could require periodic written reports from the party who initially requested the open-ended continuance in order to verify that the circumstances justifying the continuance still exist. Or, the court could require that it be informed immediately when the circumstances justifying the continuance cease to exist. Either method should suffice to ensure that most open-ended ends-of-justice continuances do not outlive their rationales. Furthermore, by placing the burden on the party who requested the continuance, each method ensures that the administrative burden of monitoring such continuances will not be a heavy one for the court.

Third, a court could adopt the "definite duration" approach and prohibit open-ended continuances entirely. This would certainly be the easiest solution for the courts to follow, bringing bright-line simplicity to an otherwise complex question. This op-

\footnotetext{
${ }^{76}$ See text accompanying notes 29-31 and 57-66.
} 
tion might also reduce the risk of dismissals since, under a "definite duration" approach, courts would know that any openended continuance would result in dismissal. Nevertheless, serious questions remain as to whether such an approach would be consistent with the purpose of the ends-of-justice provision. These and similar questions are the subject of the next Section.

\section{B. Background and Legislative History}

The Supreme Court has indicated a willingness to consult the legislative history of the STA to resolve questions left unanswered by its text. ${ }^{77}$ Although the text of the STA is helpful in evaluating the viability of the "reasonable duration" approach to open-ended continuances, it is not so helpful in evaluating the approaches compatible with Henderson. To evaluate these approaches, it is necessary to follow the Supreme Court's lead and inquire into the background and legislative history of the STA.

The STA arose from Congress's dissatisfaction with the direction of Supreme Court jurisprudence regarding the Sixth Amendment right to a speedy trial. ${ }^{78}$ Although the right to a speedy trial is the first right listed in the Sixth Amendment, and one of the oldest rights recognized in the Constitution, ${ }^{79}$ it has received relatively little attention from the Supreme Court. ${ }^{80} \mathrm{In}$ deed, the Court did not even set forth criteria by which to judge the right to a speedy trial until the 1972 watershed decision, Barker $v$ Wingo. ${ }^{81}$ That case involved a five-year delay between the defendant's indictment for murder and his trial. ${ }^{82}$ The Court

" See United States v Taylor, 487 US 326, 333 (1988) ("Because Congress employed somewhat broad and open-ended language, we turn briefly to the legislative history of the [Speedy Trial] Act for some additional indication of how the contemplated choice of remedy should be made.").

is The Sixth Amendment states:

In all criminal prosecutions, the accused shall enjoy the right to a speedy and public trial, by an impartial jury of the State and district wherein the crime shall have been committed, which district shall have been previously ascertained by law, and to be informed of the nature and cause of the accusation; to be confronted with the witnesses against him; to have compulsory process for obtaining witnesses in his favor, and to have the Assistance of Counsel for his defence.

US Const, Amend VI.

79 The origins of the speedy trial right extend back to the English Assize of Clarendon in 1166 and the Magna Carta of 1215; the right was set forth in the Virginia Declaration of Rights of 1776, the first colonial bill of rights. See Warren Freedman, The Constitutional Right to a Speedy and Fair Criminal Trial 6 (Quorum 1989).

See Barker v Wingo, 407 US 514, 515 (1972) ("Although a speedy trial is guaranteed the accused by the Sixth Amendment to the Constitution, this Court has dealt with that right on infrequent occasions.").

407 US 514, 515-16 (1972).

Id at 516-18. 
explicitly declined the defendant's invitation to hold that trials must commence "within a specified time period."83 The Court rejected the specific time limit approach first on institutional grounds, declaring that "such a result would require this Court to engage in legislative or rulemaking activity, rather than in the adjudicative process to which we should confine our efforts ...." The Court also objected on constitutional grounds, finding "no constitutional basis for holding that the speedy trial right can be quantified into a specified number of days or months." ${ }^{44}$

Instead of requiring a specific time limit, the Court opted for an ad hoc balancing test designed to provide a case-by-case analysis of relevant constitutional factors:

We can do little more than identify some of the factors which courts should assess in determining whether a particular defendant has been deprived of his right. Though some might express them in different ways, we identify four such factors: Length of delay, the reason for the delay, the defendant's assertion of his right, and prejudice to the defendant. ${ }^{85}$

The Court then applied this test and found that the five-year delay between the indictment and trial did not deprive the defendant of his right to a speedy trial. This result was principally due to the lack of prejudice resulting from the delay and the defendant's failure to object to the various continuances until near the end of the delay. ${ }^{86}$

Congress was highly critical of the Barker test, declaring that " $[t]$ he task of balancing these factors and arriving at a conclusion which is fair in all cases is a difficult task. It provides no guidance to either the defendant or the criminal justice system. It is, in effect, a neutral test which reinforces the legitimacy of

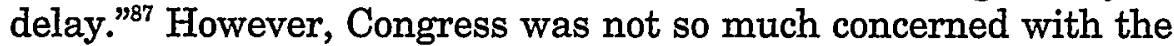
implications of the Barker decision for criminal defendants as it was with the implications of that decision for society. As the Court observed in Barker,

[T]here is a societal interest in providing a speedy trial which exists separate from, and at times in opposition to, the interests of the accused. The inability of courts to pro-

${ }^{83}$ Id at 523.

${ }^{84}$ Id.

s Id at 530.

${ }^{86}$ Id at 534-36.

${ }^{87}$ Speedy Trial Act, HR Rep No 93-1508, 93d Cong, 2d Sess 11 (1974), reprinted in 1974 USCCAN 7401, 7405. 
vide a prompt trial has contributed to a large backlog of cases in urban courts which, among other things, enables defendants to negotiate more effectively for pleas of guilty to lesser offenses and otherwise manipulate the system. In addition, persons released on bond for lengthy periods awaiting trial have an opportunity to commit other crimes. ${ }^{88}$

These concerns inspired Congress to enact the STA. The statement of purpose of the House Report on the STA declared that "[t]he purpose of this bill is to assist in reducing crime and the danger of recidivism by requiring speedy trials and by strengthening the supervision over persons released pending trial." ${ }^{289} \mathrm{In}$ deed, Congress's intention to protect society's interest in speedy trials is a recurrent theme in the legislative history. In a number of places, the House Report discusses the economic benefits to society of eliminating long pretrial delays ${ }^{90}$ and the additional deterrence and rehabilitation that would result from decreasing pretrial delays. ${ }^{91}$ Though not ignoring the interests of the accused, the House Report shows that Congress was merely concerned with ensuring that defendants' rights would not be harmed by the proposed legislation. ${ }^{92}$

${ }^{63}$ Barker, 407 US at 519.

${ }^{89}$ HR Rep No 93-1508 at 8, reprinted in 1974 USCCAN at 7402 (cited in note 87).

${ }^{\infty}$ According to the legislative history:

The Committee believes that the right to a speedy trial belongs not only to the defendant, but to society as well. A defendant who is charged with a violation of the law becomes a burden to society in the sense that his status consumes the time and energy of all components of the criminal justice system with which he comes in contact: the police, magistrate, clerks of court, probation officers, judges and others.

This creates a financial as well as an administrative burden on the taxpayer. When a defendant is detained pending trial, the taxpayer must bear the burden of sustaining him for an indefinite length of time. Most significantly, the defendant may be a danger to the community in which he resides. In the Federal system, although no exact national data is presently available, it is estimated that three-quarters of all defendants are released awaiting trial. This means that persons who are likely to commit additional crimes could without adequate supervision and assistance continue to reap the profits of criminal activity at the expense of the public.

HR Rep No 93-1508 at 15, reprinted in 1974 USCCAN at 7408-09 (cited in note 87).

${ }^{51}$ Id at 16 ("The Committee concurs in the views of the recent Courts report of the National Advisory Commission on Criminal Justice Standards and Goals which concluded that faster and efficient criminal processing would increase the deterrent effect of the criminal law, ease the task of rehabilitation of offenders and reduce crime.").

${ }^{52}$ Id at 14 concludes:

The Committee finds that placing time limits on criminal proceedings would not have a detrimental effect on the rights of defendants. The history of speedy trial legislation has shown that both the defense and the prosecution rely upon delay as a tactic in the trial of criminal cases. However, from the defendant's point of view, delay is not synonymous with due process. A defendant who is required to wait long periods to be tried suffers from a magnitude of disabilities which in no way contrib- 
Such statements of legislative purpose are highly probative of Congress's intent in passing the STA. Congress, by its own words, intended the STA to remedy the deficiencies of the Barker test, to vindicate society's interest in speedy justice as a means of reducing recidivism, and to increase deterrence and rehabilitation of criminal defendants. At the time of the STA's passage, Congress saw the statute as a procedural tool that would facilitate society's interest in justice.

These broad-based statements of legislative purpose do not tell a complete story, however. The specific legislative history surrounding the ends-of-justice provision suggests that the STA also was intended to provide trial courts with flexibility. Although the House Report discusses the ends-of-justice exclusion only briefly, it does indicate that the purpose of the exclusion is "to provide the Court with the flexibility to extend the time limits of the bill so that they will not operate harshly on the defendant, the government or society. ${ }^{\prime 93}$ Here, then, is the flexibility concern that the First and Third Circuits found so compelling in Rush and Lattany.

Testimony concerning earlier drafts of the STA is also instructive on the question of legislative intent with respect to ends-of-justice continuances. At least six different versions of the STA were proposed before the final version was enacted, and each bill contained some variation of the ends-of-justice exclusion or a similar (though broader) "good cause" exclusion. Although the legislative history of the final enactment is silent on the question of open-ended continuances, there is one reference to open-ended continuances in the legislative history of one of the earlier versions of the STA. The Ervin bill, introduced on February 22,1971 , excluded "any periods of delay resulting from a continuance granted at the request of either party upon a showing of good cause." ${ }^{\text {94 }}$ The excludable delay was limited to seven days. At the Senate hearings, one witness, Daniel Rezneck, testified in opposition to the seven-day limitation and discussed the problem of open-ended continuances:

ute to his well being. If he is incarcerated awaiting trial, unnecessary delay in the commencement of trial could result in irreparable injury to an innocent individual. To one who is ultimately found guilty of a criminal offense, the time spent in detention may represent added time to his ultimate sentence and further retard the rehabilitative process.

${ }^{33}$ Id at 22. See also Speedy Trial Act, S Rep No 93-1021, 93d Cong, 2d Sess 39 (1974), reprinted in Anthony Partridge, Legislative History of Title I of the Speedy Trial Act of 1974161 (Fed Judicial Center 1980) ("[Section 3161(h)(8)] allows for the necessary flexibility to make 90 day trials a realistic goal ....").

${ }^{9}$ Partridge, Legislative History at 137-38 (cited in note 93 ). 
The statute or the legislative history should make clear that open-ended continuances will not extend the 60 day period and that a substantial showing of good cause is required for any continuance by either side. But judicial control of continuances through the good cause requirement seems to us a better method of preventing abuses than the strict 7 day provision presently provided for. ${ }^{95}$

Several plausible inferences can be drawn from Congress's failure, in light of this testimony, to prohibit open-ended continuances under the STA. One such inference is that Congress was receptive to open-ended continuances. Given that Congress was made aware of the problem during hearings and nevertheless chose not to act, this is not an unreasonable inference. It remains questionable, however, given the substantial differences between the Ervin bill and the STA. Testimony by a nonlegislator given in response to a different provision of a different bill simply may not have been considered in drafting the final version of the STA, particularly since hearings on the Ervin bill may have been sparsely attended. Drafters of the STA may simply have been unaware of Rezneck's testimony. Nevertheless, the testimony raises at least the possibility that drafters of the STA were aware of the supposed threat of open-ended continuances and chose not to prohibit them. Though not overwhelming, this evidence lends some support to the claim that open-ended continuances were within Congress's contemplation in drafting the STA.

On the other hand, there is strong evidence that Congress feared circumvention of the STA through the ends-of-justice exclusion. The 1974 Senate Committee Report expressed the view that the ends-of-justice balancing test was designed precisely to address this danger:

In order to avoid the pitfalls of unnecessary rigidity on the one hand, and a loop-hole which would nullify the intent of the legislation on the other, a balancing test is established in order to enable the judge to determine when the "ends of justice" require an extraordinary suspension of the time limits. ${ }^{96}$

ss Speedy Trial, Hearings on S 895 before the Subcommittee on Constitutional Rights of the Senate Committee on the Judiciary, 92d Cong, 1st Sess 35-36 (1971) (statement of Daniel A. Rezneck), reprinted in Partridge, Legislative History at 140 (cited in note 93).

${ }^{55} \mathrm{~S}$ Rep No 93-1021 at 21, reprinted in Partridge, Legislative History at 160 (cited in note 93$)$. 
A similar sentiment was expressed by Representative Cohen in the House floor debate, when he argued that the ends-of-justice continuance is not "a loophole to continue [a case] under the escape provided [in Section 3161(h)(8)]." ${ }^{\text {97 }}$

It is unclear what implications these statements have for the open-ended continuances debate. On the one hand, Congress's fear that the ends-of-justice provision might be abused to circumvent the STA matches the Ninth and Second Circuits' fears that the exception could swallow the rule. On the other hand, the Senate Committee Report spoke of the "pitfalls of unnecessary rigidity" and expressed the view that the balancing test used to evaluate when an ends-of-justice continuance is appropriate was sufficient to protect against such circumvention.

If nothing else, the legislative history of the STA explains why the courts of appeals disagree about the proper approach to open-ended continuances. The history sets forth two competing interests, one rooted in efficiency and the other in flexibility. It provides no guidelines as to how to reconcile these interests when they come into conflict. It raises concerns about the endsof-justice continuance being used as a loophole, yet simultaneously expresses the opinion that a balancing test may be sufficient to eliminate that concern.

Far from rendering the legislative history of the STA irrelevant, however, these conflicts within the history demonstrate the importance of adopting a balanced proposal like the "reasonable relation" approach. The fact that two conflicting policy interests are asserted with equal conviction in the legislative history points towards the necessity of a solution that accommodates both interests. Such a solution favors allowing open-ended continuances under narrow circumstances, carefully limiting those circumstances so as to prevent the ends-of-justice exclusion from undermining the goals of the STA.

Initially, the legislative history suggests a willingness on the part of Congress to allow some open-ended continuances. That Congress chose not to prohibit open-ended continuances even after the witness who testified at the Ervin hearing suggested that it do so may provide some historical support for the claim that the STA is not averse to all open-ended continuances. More importantly, the House Report's declaration that the ends-of-justice exclusion was designed to provide flexibility and to prevent the STA from operating harshly also argues strongly in favor of al-

${ }^{97}$ Colloquy, 1974 House Floor Debate, in 120 Cong Rec H41793 (Dec 20, 1974), reprinted in Partridge, Legislative History at 174 (cited in note 93). 
lowing open-ended continuances in circumstances where failure to do so could result in harsh consequences or unnecessary rigidity. Thus, these portions of the legislative history appear to disfavor the Ninth Circuit's "definite duration" approach. Categorical denial of open-ended continuances undoubtedly would result in harsh or unnecessarily rigid results in cases like Rush, where it is impossible to set a specific trial date.

This evidence notwithstanding, the legislative history also suggests that any open-ended continuances approach must be narrowly defined. The fact that Congress declared repeatedly that the ends-of-justice exclusion should be carefully circumscribed so as not to defeat the function of the STA suggests that unconstrained open-ended continuances are impermissible. That certainly rules out adoption of the Rush approach, particularly where it is not limited by a reasonableness requirement. The unconstrained $R u s h$ approach ${ }^{98}$ would potentially permit unlimited delays based on a single open-ended continuance granted at any time in the criminal proceedings. The potential for the exception to swallow the rule is unmistakable.

In contrast, the "reasonable relation" approach provides an excellent balance between the two competing interests expressed in the legislative history. With respect to flexibility, the "reasonable relation" approach permits open-ended ends-ofjustice continuances so long as they remain tied to their rationales. That should prevent harsh or rigid application of the STA in federal criminal cases. Likewise, with respect to efficiency, the "reasonable relation" approach curbs abuse in two separate ways. First, under the Beech-Nut expression of the "reasonable relation" approach, an open-ended continuance ceases to be valid as soon as its rationale ceases to apply. Thus, ends-of-justice continuances could not remain in force long after the circumstances justifying them have faded away. Second, under the Gambino modification, open-ended continuances must be limited in time. This acts as an independent check on the risk of unacceptably long delays. ${ }^{99}$

\footnotetext{
$\because$ See text accompanying notes 75-76.

: Of course, this second quality might also be advanced in defense of the "reasonable duration" approach, in that a reasonableness limitation also acts as an independent check on unlimited delays. But whereas the "reasonable duration" approach created a general reasonableness limitation imposing an artificial time limit on all open-ended continuances, Gambino merely reaffirmed that no open-ended continuance may be unlimited in duration. Only the latter is consistent with the text of the STA. See Part III.A.
} 


\section{District Court Speedy Trial Plans}

To the extent that doubts remain, they can be mitigated by reference to the STA's implementation through speedy trial plans. In the past, several courts of appeal have examined pertinent district speedy trial plans in deciding whether an openended continuance is permissible under the STA. Such plans have been in effect for almost two decades without drawing any adverse response from Congress. Though these plans are not binding on the appellate courts, they are often used as evidence of congressional intent. ${ }^{100}$ Section 3166 was intended to give the district courts some discretion in enforcing the terms of the STA. The fact that a number of district court plans apparently permit open-ended ends-of-justice continuances may therefore be seen as compelling evidence that the STA permits some such continuances to fall within the discretion of the district courts.

In addition to the plans for Maine and the Eastern District of Pennsylvania, discussed in Rush and Lattany respectively, it appears that an identical endorsement of open-ended continuances exists in the district court plan for the Northern District of Georgia. ${ }^{101}$ All three of these plans appear to be based on the Model Statement of Time Limits and Procedures, provided by the Administrative Office of the United States Courts. Paragraph 9(d)(3) of the Model Statement, like each of the three district court plans, permits the duration of an ends-of-justice continuance to be "determined by reference to an event (such as recovery from illness) not within the control of the government." ${ }^{\prime 102}$ Like the three district court plans, the Model Statement also authorizes the trial court to require one or both parties "to file periodic reports bearing on the continued existence of such circumstances [justifying the continuance]. ${ }^{103}$

The fact that this provision has remained unchanged for two decades, and that Congress has never seen fit to alter the provision or any district court speedy trial plan based on the provision, suggests that open-ended continuances are within the con-

\footnotetext{
${ }^{100}$ See, for example, Rush, $738 \mathrm{~F} 2 \mathrm{~d}$ at $508 \mathrm{n} 23$, and Lattany, $982 \mathrm{~F} 2 \mathrm{~d}$ at 881.

${ }^{101}$ United States v Burke, $673 \mathrm{~F}$ Supp 1574, 1578 (N D Ga 1986) (“Open-ended continuances were clearly contemplated by the drafters of the Plan for the United States District Court for the Northern District of Georgia for Achieving Prompt Disposition of Criminal Cases. See Paragraph 11(b) ('If the continuance is to a date not certain, the Court shall require one or both parties to inform the Court promptly when and if the circumstances that justify the continuance no longer exist.')."), affd, 856 F2d 1492 (11th Cir 1988).

${ }^{102}$ Report on the Implementation of Title I and Title II of the Speedy Trial Act of 1974 59 (Admin Office of the US Courts 1976).

${ }^{103}$ Id.
} 
gressional understanding of the STA. Even assuming, as could well be the case, that Congress's lack of reaction is due to simple inattention or disinterest, the fact that numerous district courts and the Administrative Office of the United States Courts have exercised their Section 3166 powers in an uninterrupted manner to authorize open-ended continuances offers strong independent grounds to defer to their rulemaking judgments.

Where Rush and Lattany erred, however, was in concluding that this provision could justify the "reasonable duration" approach. The provision much more strongly supports the "reasonable relation" approach. Allowing the duration of an endsof-justice continuance to be tied to the particular circumstances justifying its existence is a hallmark of the "reasonable relation" approach. The validity of the continuance is contingent upon the continued existence of those facts justifying it. Additionally, the requirement that the continuance be conditioned upon periodic reports affirming the continuing existence of the justifying circumstances falls firmly under the "reasonable relation" umbrella. What the district court plans and the Model Statement suggest, then, is that an open-ended continuance is permissible so long as the rationale supporting the continuance remains in effect. Put another way, an open-ended ends-of-justice continuance is valid so long as it remains reasonably related to its initial justification. Where the justification for the continuance ends, or a definite end date for the continuance becomes clear, the reasonable relationship is severed and the open-ended continuance ceases to be valid. This analysis is more consistent with the "reasonable relation" approach than with either the "reasonable duration" or the "definite duration" approaches. Thus, Congress's accession to the various district court speedy trial plans, combined with the text and legislative history of the STA, favors a "reasonable relation" approach to open-ended ends-of-justice continuances. This approach, as outlined in LoFranco and Beech-Nut and further explored in this Section, would permit an open-ended ends-ofjustice continuance initially only if a definite end date could not be assigned at the time of the continuance's issuance, would require periodic reports affirming the continuing existence of the circumstances justifying the continuance, and would invalidate the continuance as soon as it became clear that those circumstances no longer were present. 


\section{CONCLUSION}

The text, background, legislative history, and implementation of the STA through district court speedy trial plans all lead to the conclusion that the STA permits open-ended continuances, but only those continuances that remain reasonably related to their initial rationales. To prohibit open-ended continuances entirely would be contrary to the statute's legislative history, which reveals Congress's desire to give trial courts flexibility. Conversely, to allow open-ended continuances so long as they are reasonable in length disregards the text of the STA as interpreted by the Supreme Court in United States $v$ Henderson, and permits a loophole that could swallow the STA and its efficiency objectives. Tying the validity of an open-ended ends-of-justice continuance to its initial rationale should ensure that open-ended continuances would only be granted in circumstances in which it is truly impossible to determine an end date for the continuance-and that the continuance could last only as long as it remains impossible to make such a determination. The "reasonable relation" approach therefore strikes an appropriate balance between the STA's efficiency concerns and the ends-of-justice exclusion's flexibility concerns, producing rapid justice while still affording trial judges the discretion they need to accommodate complex and unusual cases. 